\title{
Effect of Cooling Rate on AlN Precipitation in FeCrAl Stainless Steel During Solidification
}

\author{
Zhenqiang Deng ${ }^{1,2} \mathbb{D}$, Yang $\mathrm{He}^{1}$, Jianhua Liu ${ }^{1, *}$, Baijun Yan ${ }^{3}$, Yindong Yang ${ }^{2}$ \\ and Alexander McLean ${ }^{2, *}$ \\ 1 Institute of Engineering Technology, University of Science and Technology Beijing, Beijing 100083, China; \\ dengzhenqiang@outlook.com (Z.D.); ustbheyang@163.com (Y.H.) \\ 2 Department of Materials Science and Engineering, University of Toronto, Toronto, ON M5S 3E4, Canada; \\ yy9861@yahoo.com \\ 3 Department of Physical Chemistry of Metallurgy, University of Science and Technology Beijing, \\ Beijing 100083, China; baijunyan@ustb.edu.cn \\ * Correspondence: liujianhua@metall.ustb.edu.cn (J.L.); amclean16@cogeco.ca (A.M.); \\ Tel.: +86-010-62332958-6421 (J.L.); +1-416-978-1291 (A.M.)
}

Received: 12 September 2019; Accepted: 8 October 2019; Published: 11 October 2019

\begin{abstract}
The effect of cooling rate on the evolution of AlN inclusions precipitated during solidification in $\mathrm{FeCrAl}$ stainless steel was investigated using an experimental study and thermodynamic and kinetic calculations. The number and size of AlN inclusions precipitated under different cooling rates were examined with the feature function of the field-emission scanning electron microscope. A model combining micro-segregation and the diffusion-controlled growth model was set up to determine the mechanism of AlN particle growth. The results showed that AlN precipitates in the mushy zone. The size of AlN particles decreases and the number of AlN particles increases with increasing cooling rate, whereas the volume fraction is essentially unchanged. The AlN particles grow during solidification after the content of solutes in molten steel has exceeded the concentration in equilibrium with AlN. The nitrogen content varies significantly with the cooling rate during solidification. Increasing the cooling rate and reducing the nitrogen content in the molten steel can reduce the AlN particle size in FeCrAl alloys as the growth time decreases.
\end{abstract}

Keywords: FeCrAl stainless steel; AlN; solidification; micro-segregation; diffusion-controlled growth; cooling rate

\section{Introduction}

FeCrAl stainless steel is an ideal material for the production of automotive exhaust gas purifier carriers due to its excellent high-temperature oxidation resistance and low thermal expansion coefficient [1,2]. In order to form a dense aluminum oxide film at high temperatures to obtain good oxidation resistance, the $\mathrm{Al}$ content in FeCrAl stainless steel is usually above 3\% [3]. The thickness of the steel foil used is only $30-50 \mu \mathrm{m}$, and a suitable solidification structure with good plasticity is required in order to ensure reliable yield and surface quality. The composition, size and distribution of inclusions significantly affect the structure and properties of the cast slab [4]. There have been many reports on the characteristics of $\mathrm{Al}_{2} \mathrm{O}_{3}$ and $\mathrm{AlN}$ inclusions in regular Al-killed steels [5-8]. In these steels, the dissolved oxygen is very low because of the strong deoxidizing power of $\mathrm{Al}$ and thus there is relatively little oxide precipitation during solidification [9]. In the FeCrAl stainless steel, AlN inclusions are the dominant precipitates [10]. These inclusions cannot play an effective role in the heterogeneous nucleation of ferrite and can also cause embrittlement and induce cracking phenomena such as rock candy fracture during continuous casting and hot rolling [11-13]. Some authors [14,15] 
report that the AlN precipitates cause low hot ductility by inhibiting dynamic recrystallization and by grain boundary pinning, which is considered to facilitate void formation. Thus, it is important to control the precipitation of AlN inclusions in $\mathrm{FeCrAl}$ stainless steel.

Most of the inclusions formed during the deoxidation of steel are removed in the process of argon stirring in the ladle and the remainder should be removed in the tundish. Ideally, there should be almost no inclusions in the steel during the casting process [16]. However, in the mold, inclusions can form in the molten steel for two reasons: the equilibrium solubility product decreases with the decrease in temperature, and the solutes are redistributed at the solidification front. During the solidification of steel, micro-segregation results in an enrichment of solutes in the liquid phase, which can lead to the formation and growth of the inclusions [17]. Han et al. [18] found that during solidification, AlN precipitated after the solid fraction reached 0.85 in FeCrAl stainless steel which contained 0.02-0.06 weight percent Ti.

To gain a deeper understanding of the formation and growth of inclusions in steel, thermodynamics and kinetics have been widely applied for the evaluation and control of inclusion formation during casting. There are three mechanisms contributing to the growth of inclusions: diffusion-controlled growth, collisions and coarsening [19-21]. Many experimental and mathematical studies [22-28] have been carried out on micro-segregation and inclusion precipitation during solidification. However, in most models, the micro-segregation of solute elements and the precipitation of inclusions were calculated separately, which tends to overestimate the degree of micro-segregation and the amount of inclusions. Thus, coupled micro-segregation and thermodynamic models are advantageous for the precise evaluation of inclusion formation during solidification.

The cooling rate is one of the critical parameters in the solidification process which has an important influence on the formation of crystal grains, the growth of crystals, and the size and distribution of precipitates. Controlling the cooling rate to obtain optimal microstructure and precipitates is of great significance with respect to the optimization of the controlled rolling process and subsequent cooling of the steel sheet.

In the present work, the cooling rate was varied during unidirectional solidification to determine the effect on the precipitation of AlN in FeCrAl stainless steel. The morphology, number density and size distribution of AlN particles were quantitatively analyzed in samples solidified under different cooling rates. The precipitation of AlN was also predicted using a micro-segregation model combined with a diffusion-controlled growth model. Based on relevant solidification parameters, the enrichment of solutes in molten steel and the size of the AlN particles formed during solidification have been calculated. The results predicted from the model have been compared with observations of inclusions in the $\mathrm{FeCrAl}$ alloy samples.

\section{Materials and Methods}

An FeCrAl alloy ingot was produced in a $25 \mathrm{~kg}$ vacuum induction furnace with commercial purity materials. The chemical composition of the alloy is given in Table 1.

Table 1. Chemical composition of the FeCrAl alloy.

\begin{tabular}{ccccccccccc}
\hline $\begin{array}{c}\text { Chemical } \\
\text { Component }\end{array}$ & C & Si & Mn & Cr & P & S & N & O & Al & $\begin{array}{c}\text { Fe }+ \\
\text { Other }\end{array}$ \\
\hline wt. $\%$ & 0.022 & 0.13 & 0.20 & 19.90 & 0.0058 & 0.0045 & 0.0088 & 0.0020 & 4.07 & balance \\
\hline
\end{tabular}

Rod samples, $5.5 \mathrm{~mm}$ in diameter and $110 \mathrm{~mm}$ in length, were cut from the ingot, and placed in an alumina tube which was located within a vacuum Bridgeman unidirectional solidification furnace, a schematic diagram of which is shown in Figure 1. All the tests were performed under an argon atmosphere to avoid specimen oxidation. Four rod samples (labeled A, B, C and D) were heated to $1873 \mathrm{~K}$ at a constant heating rate of $10 \mathrm{~K} / \mathrm{s}$, held for $30 \mathrm{~min}$ and then directionally solidified under a constant temperature gradient $\left(1.5 \times 10^{4} \mathrm{~K} / \mathrm{m}\right)$ at a growth rate of $25 \mu \mathrm{m} / \mathrm{s}, 50 \mu \mathrm{m} / \mathrm{s}, 100 \mu \mathrm{m} / \mathrm{s}$ and 
$200 \mu \mathrm{m} / \mathrm{s}$, respectively. The corresponding cooling rates $\left(R_{c}\right)$ are $0.375,0.75,1.5$, and $3 \mathrm{~K} / \mathrm{s}$. The growth length of the samples was $50 \mathrm{~mm}$ and at the end of the experiments, the samples were quenched with liquid coolant.

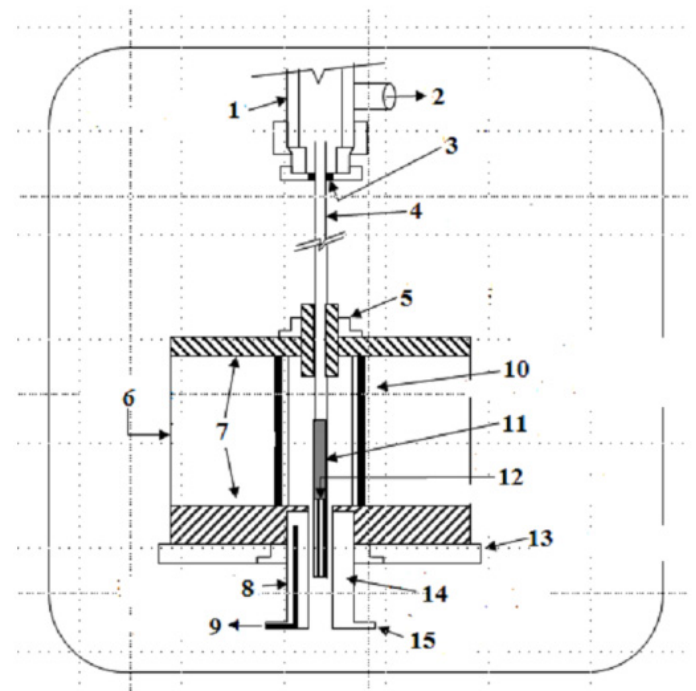

Figure 1. Schematic diagram of the Bridgeman unidirectional solidification furnace. 1. vacuum chamber; 2 . vacuum system; 3 . O ring; 4. alumina tube; 5 . gripper; 6 . furnace; 7 . insulating layer; 8. cold finger; 9 . cooling water outlet; $10 . \mathrm{MoSi}_{2}$ heater; 11 . liquid phase; 12 . solid phase; 13 . movable bottom bracket; 14 . spiral water jacket; 15 . cooling water inlet.

The quenched samples were sectioned in the middle along the growth direction, on which the morphology of inclusions was observed with a field-emission scanning electron microscope (FESEM, MLA 250, FEI Quanta, Hillsboro, OR, USA) after the conventional polishing. Then, the composition, number and size of the inclusions in the area of $59.5 \mathrm{~mm}^{2}$ within the first $20 \mathrm{~mm}$ length of each sample were measured automatically with the feature function of the FESEM. The size of the particle equals the diameter of the disc of equal area content.

\section{Results and Discussion}

\subsection{Morphology of AlN Particles}

According to FESEM observations, AlN is the dominant precipitate in the experimental FeCrAl stainless steel. Typical AlN particles observed in different samples are shown in Figure 2. The planar sections of most of the AlN particles are hexagonal for all four cooling rates.

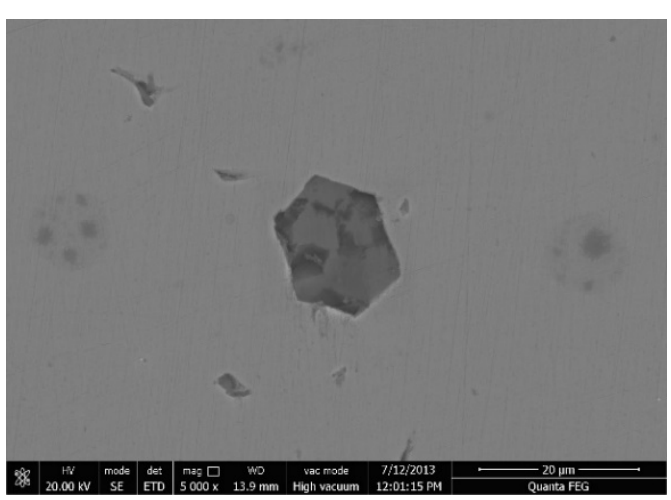

(a)

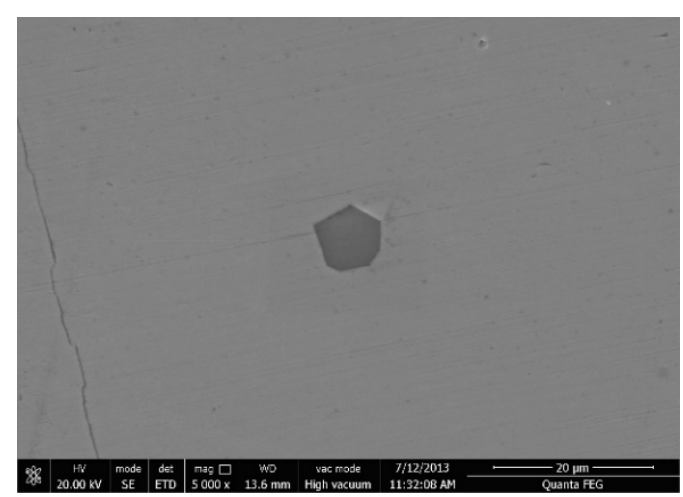

(b)

Figure 2. Cont. 


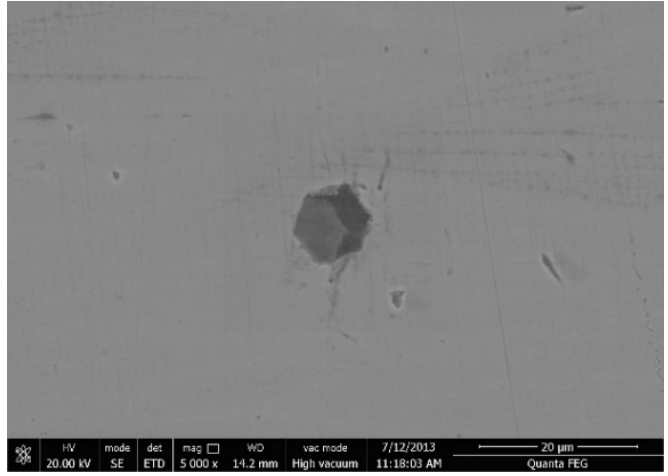

(c)

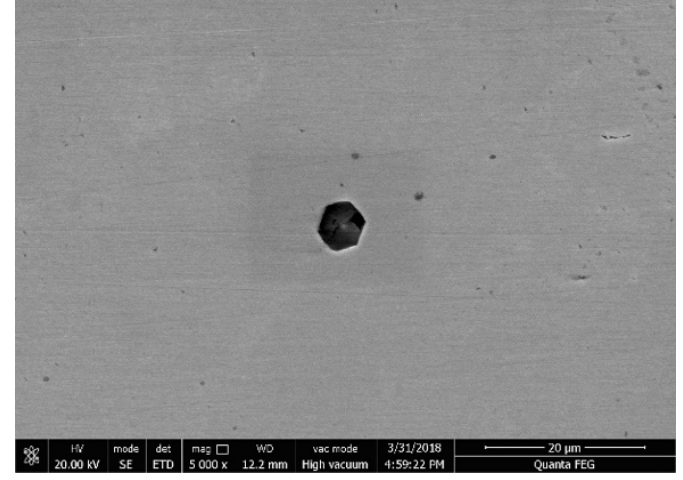

(d)

Figure 2. Morphologies of AlN particles in samples for four cooling rates: (a) $0.375 \mathrm{~K} / \mathrm{s}$, (b) $0.75 \mathrm{~K} / \mathrm{s}$, (c) $1.5 \mathrm{~K} / \mathrm{s},(\mathrm{d}) 3 \mathrm{~K} / \mathrm{s}$.

\subsection{Number and Size Distribution of AlN Particles}

The number of AlN particles per unit volume of steel, $N_{V}\left(\mathrm{~m}^{-3}\right)$, was obtained using the Saltykov and Fullman equations (Equations (1) and (2)) [29]. The volume fraction of inclusions, $V_{V}$, was calculated using Equation (3).

$$
\begin{aligned}
& N_{V}=\frac{2}{\pi} \cdot \frac{N_{A}}{\bar{d}} \\
& \frac{1}{\bar{d}}=\frac{1}{n} \cdot \sum \frac{1}{d_{i}} \\
& V_{V}=\frac{\pi}{6} \bar{d}^{3} \cdot N_{V}
\end{aligned}
$$

where $N_{A}\left(\mathrm{~m}^{-2}\right)$ is the number of AlN particles per unit area in steel, $d_{i}(\mathrm{~m})$ is the apparent diameter of the $i$ th AlN particle, $n$ is the total number of AlN particles that have been measured, and $\bar{d}(\mathrm{~m})$ is the harmonic mean of AlN particle diameters.

The results of calculation for the average size, number density and volume fraction of AlN in $\mathrm{FeCrAl}$ alloys with different cooling rates are shown in Figure 3. As the cooling rate increases from $0.375 \mathrm{~K} / \mathrm{s}$ to $3 \mathrm{~K} / \mathrm{s}$, the average size of the AlN particles decreased from $8.09 \mu \mathrm{m}$ to $4.99 \mu \mathrm{m}$ and the number density increased from $17.85 \mathrm{~mm}^{-2}$ to $43.92 \mathrm{~mm}^{-2}$, whereas the volume fraction was relatively unchanged. This confirms that AlN precipitated under the experimental conditions and that the size and number of AlN particles changed with the varying cooling rate, although there was no significant change in the total mass of AlN.

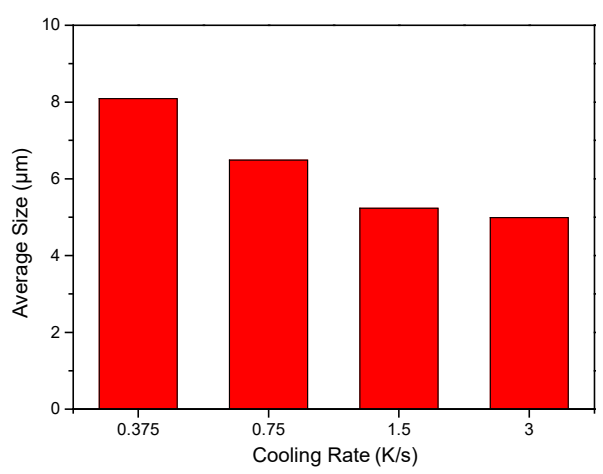

(a)

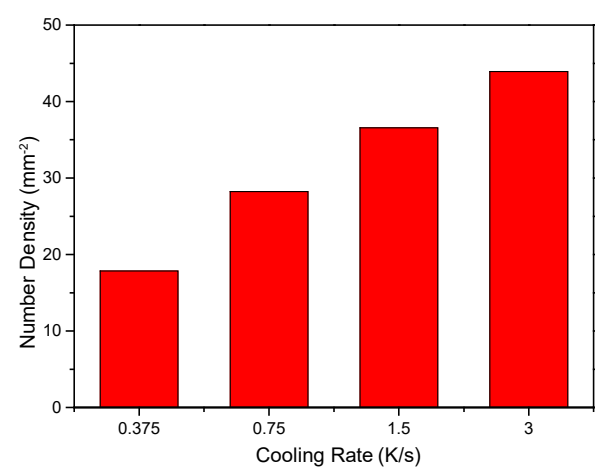

(b)

Figure 3. Cont. 


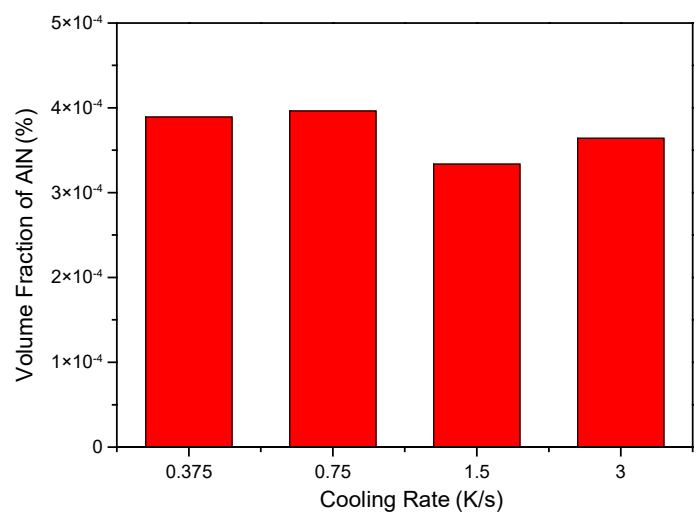

(c)

Figure 3. Comparison of average size, number density and volume fraction of $\mathrm{AlN}$ in FeCrAl alloys with different cooling rates. (a) Average size of $\mathrm{AlN}$; (b) number density of $\mathrm{AlN}$; (c) volume ratio of AlN.

In Figure 4, a comparison is shown of the diameter distribution of AlN particles with different cooling rates, calculated from the measured results which were obtained using the feature function of the FESEM. When the cooling rate is $3 \mathrm{~K} / \mathrm{s}$, most of the AlN particle diameters are less than $8 \mu \mathrm{m}$ and their cumulative frequency is $93 \%$. When the cooling rate decreased to $1.5 \mathrm{~K} / \mathrm{s}, 0.75 \mathrm{~K} / \mathrm{s}$ and $0.375 \mathrm{~K} / \mathrm{s}$, the peak number percentage moved towards a larger size and the cumulative frequencies of AlN particles with a diameter less than $8 \mu \mathrm{m}$ was $83 \%, 64 \%$, and $36 \%$, respectively.
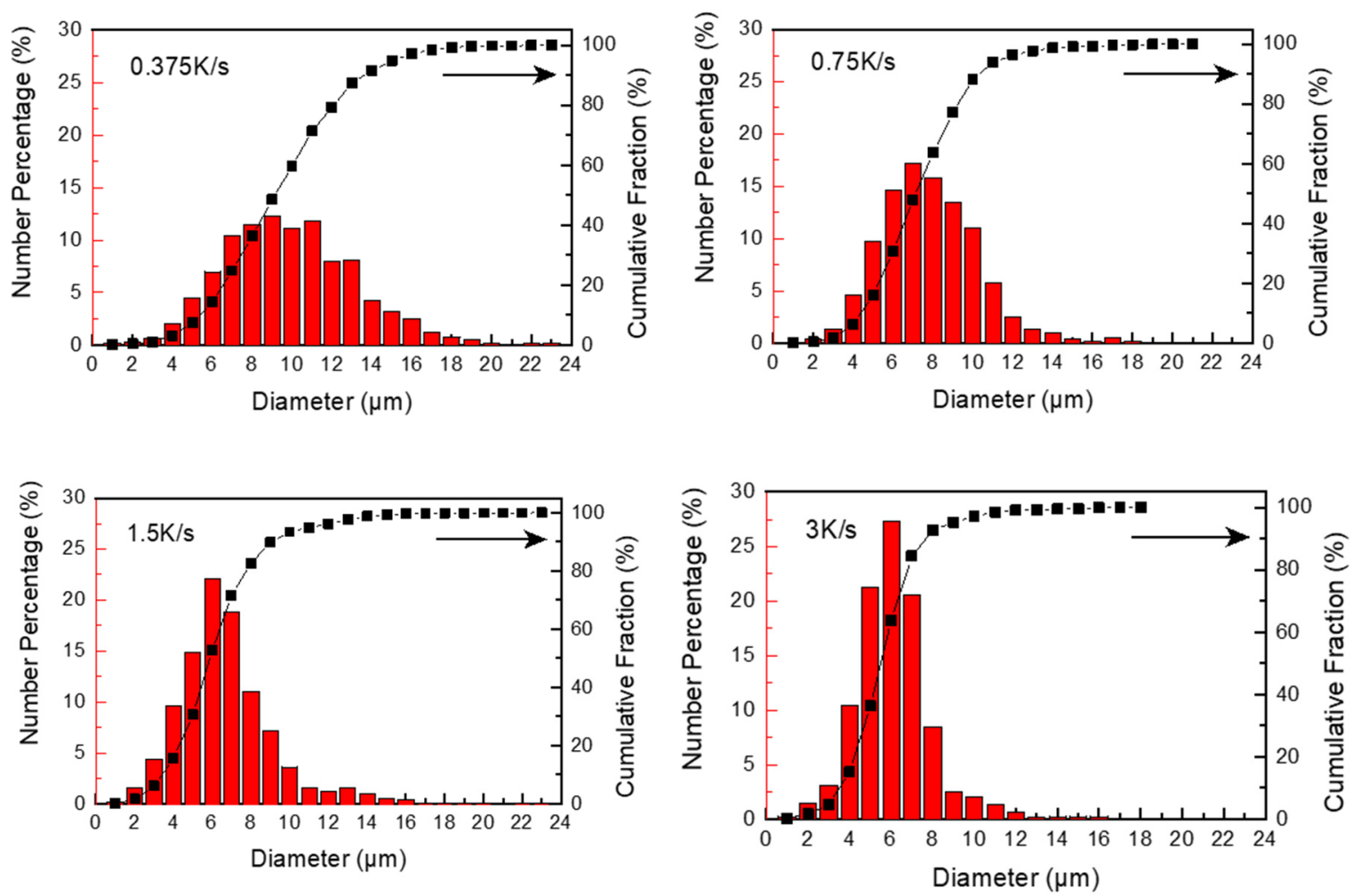

Figure 4. Size distribution of AlN particles with different cooling rates.

\subsection{Precipitation of AlN}

The thermodynamic conditions for AlN precipitation in the experimental alloy were evaluated with Factsage software by using the "Scheil-Gulliver cooling" option. As shown in Figure 5, the 
liquidus and solidus temperatures $\left(T_{l}, T_{S}\right)$ are $1795.9 \mathrm{~K}$ and $1774.4 \mathrm{~K}$, respectively. AlN precipitates in the mushy zone at $1788.6 \mathrm{~K}$ during the cooling process.

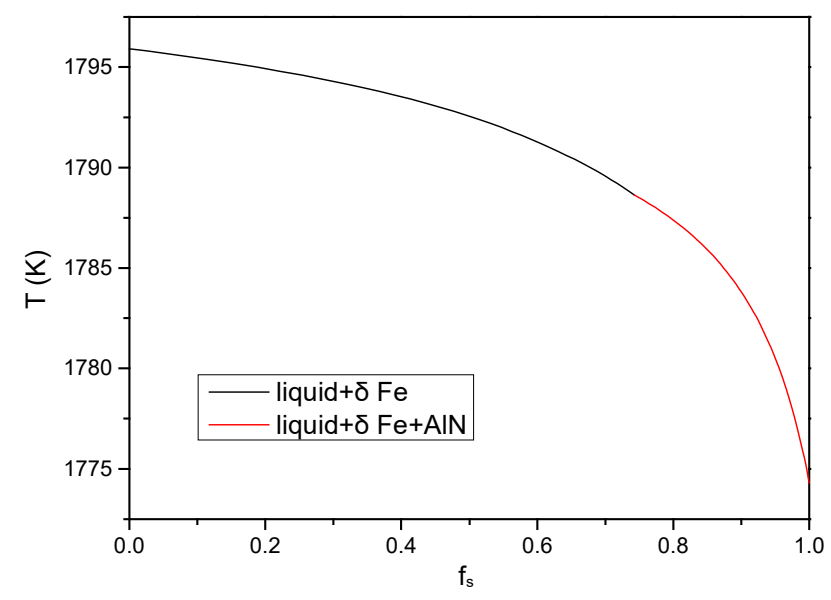

Figure 5. Phase transformations during solidification of $\mathrm{FeCrAl}$ alloys.

Since AlN inclusions precipitate in the mushy zone and the number and size of AlN particles change with the cooling rate, the coarsening mechanism of AlN was analyzed by combining a micro-segregation of solutes model with a diffusion-controlled growth model.

Micro-segregation of solutes was calculated using Ohnaka's equation (Equation (4)) [30].

$$
\begin{gathered}
\frac{\mathrm{d} C_{\mathrm{L}}}{C_{\mathrm{L}}}=\frac{\left(1-k_{i}\right) \mathrm{d} f_{\mathrm{s}}}{1-\left(1-\frac{\beta k_{i}}{1+\beta}\right) f_{s}} \\
\beta=\frac{4 D_{i}^{s o l} t_{f}}{\lambda^{2}} \\
t_{f}=\frac{\left(T_{l}-T_{s}\right)}{R_{c}}
\end{gathered}
$$

where $C_{\mathrm{L}}$ is the concentration of solute in the liquid phase, $k_{i}$ is the equilibrium distribution coefficient of solute $i, f_{s}$ is the solid fraction, $\beta$ is the back diffusion parameter, $D_{i}^{s o l}\left(\mathrm{~m}^{2} \mathrm{~s}^{-1}\right)$ is the diffusion coefficient of solute $i$ in a solid, $\lambda(\mathrm{m})$ is the secondary dendrite arm spacing and $t_{f}(\mathrm{~s})$ is the local solidification time. According to the results of Factsage calculations, the local solidification times for samples A, B, C and D are 57.39 s, 28.69 s, 14.35 s, and 7.17 s, respectively. Precipitation of AlN began at $f_{s}=0.743$.

The secondary dendrite arm spacing was calculated using the correlation proposed by Won and Thomas [31] which is suitable for carbon contents less than 0.15 mass $\%$.

$$
\lambda=\left(169.1-720.9 C_{C}\right) R_{c}^{-0.4935}(\mu \mathrm{m})
$$

where $C_{C}$ is the carbon content in mass percent.

Since the FeCrAl alloy corresponds to a ferritic stainless steel, the transition that occurs during the solidification process is the transformation from the liquid phase to the $\delta$ phase [32,33]. The equilibrium distribution coefficient of nitrogen between the $\delta$ phase and liquid steel $\left(k_{N}\right)$ is 0.25 [16]. The diffusion coefficient of nitrogen in the $\delta$ phase was determined using Equation (8) [16].

$$
D_{\mathrm{N}}^{\delta}=8 \times 10^{-7} \exp (-79,078 / R T)
$$


The following equilibrium reaction was assumed to exist at the interface between AlN and molten steel. [34]

$$
\begin{gathered}
{[\mathrm{Al}]+[\mathrm{N}]=\mathrm{AlN}(\mathrm{s})} \\
\Delta G^{\theta}=-247,000+107.5 T
\end{gathered}
$$

where $\Delta G^{\theta}$ is the standard Gibbs free energy $(\mathrm{J} / \mathrm{mol})$.

The equilibrium constant, $K$, can be written as the following relation using Wagner's formalism [35]:

$$
\begin{gathered}
\log \left(\frac{1}{K}\right)=\log f_{\mathrm{Al}}=\log f_{\mathrm{N}}+\log [\mathrm{pctAl}][\mathrm{pctN}] \\
\log f_{\mathrm{Al}(1873)}=e_{\mathrm{Al}}^{\mathrm{Al}}[\mathrm{pctAl}]+r_{\mathrm{Al}}^{\mathrm{Al}}[\mathrm{pctAl}]^{2}+e_{\mathrm{Al}}^{\mathrm{Cr}}[\mathrm{pctCr}]+r_{\mathrm{Al}}^{\mathrm{Cr}}[\mathrm{pctCr}]^{2}+e_{\mathrm{Al}}^{\mathrm{N}}[\mathrm{pctN}]+r_{\mathrm{Al}}^{\mathrm{N}}[\mathrm{pctN}]^{2} \\
\log f_{\mathrm{N}(1873)}=e_{\mathrm{N}}^{\mathrm{Al}}[\mathrm{pctAl}]+r_{\mathrm{N}}^{\mathrm{Al}}[\mathrm{pctAl}]^{2}+e_{\mathrm{N}}^{\mathrm{Cr}}[\mathrm{pctCr}]+r_{\mathrm{N}}^{\mathrm{Cr}}[\mathrm{pctCr}]^{2}+e_{\mathrm{N}}^{\mathrm{N}}[\mathrm{pctN}]+r_{\mathrm{N}}^{\mathrm{N}}[\mathrm{pctN}]^{2}
\end{gathered}
$$

The activity coefficient of $\mathrm{Al}\left(f_{\mathrm{Al}}\right)$ was substituted for the activity coefficient of $\mathrm{Al}$ at $1873 \mathrm{~K}$ $\left(f_{\mathrm{Al}(1873)}\right)$. The activity coefficient of $\mathrm{N}\left(f_{\mathrm{N}}\right)$ was obtained by Equation (14) [25].

$$
\lg f_{\mathrm{N}}=\left(\frac{3280}{T}-0.75\right) \times \lg f_{\mathrm{N}(1873)}
$$
Table 2.

The values used for the first and second order interaction parameters $\left(e_{i}^{j}\right.$ and $\left.r_{i}^{j}\right)$ are shown in

Table 2. First and second order interaction parameters for the calculation of Al-N equilibrium in $\mathrm{FeCrAl}$ alloy at $1873 \mathrm{~K}$ [36].

\begin{tabular}{cccccccccccc}
\hline$e_{\mathrm{Al}}^{\mathrm{Al}}$ & $r_{\mathrm{Al}}^{\mathrm{Al}}$ & $e_{\mathrm{Al}}^{\mathrm{Cr}}$ & $r_{\mathrm{Al}}^{\mathrm{Cr}}$ & $e_{\mathrm{Al}}^{\mathrm{N}}$ & $r_{\mathrm{Al}}^{\mathrm{N}}$ & $e_{\mathrm{N}}^{\mathrm{Al}}$ & $r_{\mathrm{N}}^{\mathrm{Al}}$ & $e_{\mathrm{N}}^{\mathrm{Cr}}$ & $r_{\mathrm{N}}^{\mathrm{Cr}}$ & $e_{\mathrm{N}}^{\mathrm{N}}$ & $r_{\mathrm{N}}^{\mathrm{N}}$ \\
\hline 0.043 & -0.001 & 0.0122 & 0 & 0.033 & 0 & 0.017 & 0 & -0.06 & 0.0007 & 0 & 0 \\
\hline
\end{tabular}

During solidification, the growth rate of AlN may be controlled by the chemical reaction rate at the AlN/steel interface, the mass transport rate of aluminum from steel to the interface, or the mass transport rate of nitrogen from the steel to the interface [37]. Because the interfacial reaction rate is relatively fast at temperatures around $1800 \mathrm{~K}$ and the aluminum concentration is much higher than nitrogen, the mass transport rate of nitrogen from steel to the interface is likely be the restrictive step for the growth of AlN particles. The diffusion flux of nitrogen towards the AlN particle can be expressed as:

$$
J_{\mathrm{N}}=D_{\mathrm{N}}^{l i q}\left(\frac{\mathrm{d}[\mathrm{N}]_{x}}{\mathrm{~d} x}\right)_{x=r}
$$

where $J_{\mathrm{N}}\left(\mathrm{kg} \cdot \mathrm{m}^{-2} \cdot \mathrm{s}^{-1}\right)$ is the diffusion flux of nitrogen, $D_{\mathrm{N}}^{l i q}\left(\mathrm{~m}^{2} \cdot \mathrm{s}^{-1}\right)$ is the mass transfer coefficient of nitrogen in molten steel and $r(\mathrm{~m})$ is the radius of the AlN particle.

$D_{\mathrm{N}}^{l i q}\left(\mathrm{~m}^{2} \cdot \mathrm{s}^{-1}\right)$ was determined using Equation (16) [38].

$$
\lg D_{\mathrm{N}}^{l i q}=\left(-\frac{3801}{T}\right)-6.01
$$

Assuming the AlN particle is spherical, each particle grows independently and AlN particles stop growing once they are entrapped by the solid/liquid interface during solidification. The relationship between $J_{N}$ and the radius of an AlN particle can be expressed by Equation (17).

$$
\frac{M_{\mathrm{AlN}}}{M_{\mathrm{N}}} \times\left(4 \pi r^{2} J_{\mathrm{N}} \Delta t\right)=\frac{4}{3} \pi \rho_{\mathrm{AIN}}\left[(r+\Delta r)^{3}-r^{3}\right]
$$


where $M_{\text {AlN }}$ is the molar mass of AlN $(0.041 \mathrm{~kg} / \mathrm{mol}), M_{\mathrm{N}}$ is the molar mass of nitrogen $(0.0014 \mathrm{~kg} / \mathrm{mol})$ and $\rho_{\text {AlN }}$ is the density of $\operatorname{AlN}\left(3.26 \times 10^{3} \mathrm{~kg} \cdot \mathrm{m}^{-3}\right)$.

Combining Equation (15) with Equation (17), the growth of an AlN particle is expressed by Equation (18) $[9,26,39]$.

$$
r(t) \frac{\mathrm{d} r}{\mathrm{~d} t}=\frac{M_{\mathrm{AlN}}}{100 M_{\mathrm{N}}} \frac{\rho_{\mathrm{Fe}}}{\rho_{\mathrm{AlN}}} D_{\mathrm{N}}^{l i q}\left(C_{\mathrm{N}}(t)-C_{\mathrm{N}}^{e q u}\right)
$$

where $r(t)(\mathrm{m})$ is the radius of an AlN particle after time $t(\mathrm{~s})$ during solidification from liquidus to solidus temperature, $\rho_{\mathrm{Fe}}$ is the density of iron $\left(7.07 \times 10^{3} \mathrm{~kg} \cdot \mathrm{m}^{-3}\right), C_{\mathrm{N}}(t)($ mass $\%)$ is the concentration of nitrogen which is influenced by the micro-segregation between dendritic arms after time $t$ and $C_{\mathrm{N}}^{e q u}$ (mass \%) is the nitrogen concentration in equilibrium with AlN. As mentioned previously, the AlN particles precipitate in the mushy zone. For samples A, B, C, and D, the times from the beginning of solidification to the formation of AlN particles are $19.41 \mathrm{~s}, 9.71 \mathrm{~s}, 4.85 \mathrm{~s}$, and $2.43 \mathrm{~s}$, respectively. During the solidification process, nitrogen is continuously enriched in the liquid phase due to the effect of micro-segregation. When the concentration of solutes in molten steel exceeds the equilibrium value with AlN, the AlN particles will grow. The difference between $C_{\mathrm{N}}(t)$ and $C_{\mathrm{N}}^{e q u}$ is considered to be the driving force for AlN growth.

Assuming AlN particles are uniformly distributed in the steel, the steel can be considered in terms of $N_{V}$ spherical volume units, where each volume unit contains only one AlN particle. The radius (l) of the volume unit was calculated using Equation (19) [26].

$$
\frac{4 \pi}{3} l^{3} N_{V}=1
$$

The number of AlN particles per unit volume of steel $\left(N_{V}\right)$ for samples A, B, C and D calculated using Equation (1) are $1.405 \times 10^{12} \mathrm{~m}^{-3}, 2.773 \times 10^{12} \mathrm{~m}^{-3}, 4.449 \times 10^{12} \mathrm{~m}^{-3}$, and $5.606 \times 10^{12} \mathrm{~m}^{-3}$, respectively.

For the conservation of mass in each volume unit, it follows that the decrease in solute elements in the molten steel is due to the growth of AlN. The mass balance for nitrogen in a volume unit is therefore expressed by the sum of the quantity precipitated as AlN and the remaining dissolved in the steel.

$$
\frac{4 \pi}{3} l^{3} \rho_{\mathrm{Fe}} \frac{C_{\mathrm{N}}^{0}}{100}=\frac{4 \pi}{3}\left[l^{3}-r(t)^{3}\right] \rho_{\mathrm{Fe}} \frac{C_{\mathrm{N}}^{\text {steel }}(t)}{100}+\frac{4 \pi}{3} r(t)^{3} \rho_{\mathrm{AlN}} \frac{M_{\mathrm{N}}}{M_{\mathrm{AlN}}}
$$

where $C_{\mathrm{N}}^{0}$ (mass \%) is the nitrogen content in molten steel before solidification, and $C_{\mathrm{N}}^{\text {steel }}(t)($ mass \%) is the average nitrogen content of solid and liquid after time $t$.

The flow chart for the calculation is shown in Figure 6. The solid fraction mesh, $\mathrm{d} f_{s}$, is taken to be 0.0001 . First, the temperature decreases from $1873 \mathrm{~K}$ to the liquidus temperature and then solidification begins.

$$
f_{s}=f_{s}+\mathrm{d} f_{s}
$$

The nitrogen content in molten steel $\left(C_{N}\right)$ was calculated using Equation (4). The concentrations of solute elements are enriched in molten steel based on the micro-segregation model. AlN particles form when the concentrations of solutes reach the equilibrium content with $\operatorname{AlN}\left(C_{\mathrm{N}}^{e q u}\right)$, which was calculated by Factsage and Equation (11). When the concentrations of solutes exceed the equilibrium content with AlN, growth of the AlN particles will take place. The nitrogen content in molten steel was determined by the mass balance shown in Equation (22).

$$
C_{\mathrm{N}}=\frac{C_{\mathrm{N}} \rho_{\mathrm{Fe}}\left(1-f_{s}\right) l^{3}-\Delta r^{3} \rho_{\mathrm{AIN}} \frac{M_{\mathrm{N}}}{100 M_{\mathrm{AIN}}}}{\rho_{\mathrm{Fe}}\left(1-f_{s}\right) l^{3}}
$$

This calculation was repeated until the solid fraction reached one, which means the solidification process was complete. 


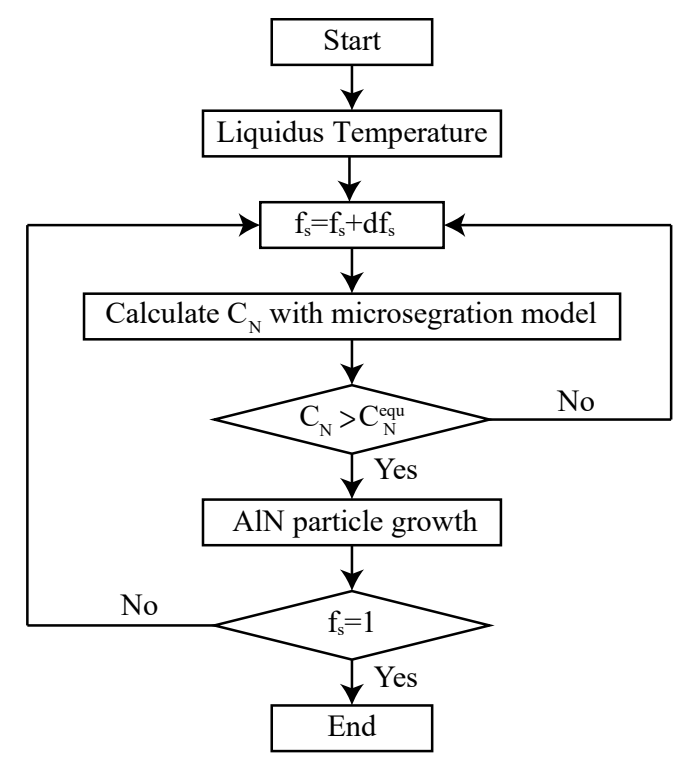

Figure 6. Flow chart for calculation of AlN particle growth.

Figures 7 and 8 show the calculated results for nitrogen content in molten steel during solidification with different cooling rates before and after the precipitation of AlN, respectively. As shown in Figure 7, before AlN precipitation, the cooling rate has little effect on the variation of nitrogen content in the molten steel with an increasing solid fraction. Figure 8 shows that after AlN begins to precipitate, the variations in nitrogen content for different cooling rates have a similar trend. The nitrogen content in the molten steel first increases and then decreases due to the growth of AlN particles.

Figure 9 shows the calculated diameters of AlN particles during solidification at different cooling rates. With increasing cooling rate, the final particle diameter decreases. Based on the AlN formation temperature and the solidus temperature, the total growth time of AlN particles for cooling rates of $0.375 \mathrm{~K} / \mathrm{s}, 0.75 \mathrm{~K} / \mathrm{s}, 1.5 \mathrm{~K} / \mathrm{s}$, and $3 \mathrm{~K} / \mathrm{s}$ are $37.97 \mathrm{~s}, 18.99 \mathrm{~s}, 9.49 \mathrm{~s}$, and $4.75 \mathrm{~s}$, respectively, and the particle diameters at the end of solidification are $8.27 \mu \mathrm{m}, 6.60 \mu \mathrm{m}, 5.65 \mu \mathrm{m}$, and $5.25 \mu \mathrm{m}$. These values are in excellent agreement with the actual measured diameters shown in Figure $3 \mathrm{a}$.

Comparing Figures $8 b$ and $9 b$, as the cooling rate increases, the solidifying velocity increases and the nitrogen content at the same growth time is higher during the period of nitrogen enrichment. The driving force for the growth of $\operatorname{AlN}\left(C_{N}-C_{N}^{e q u}\right)$ increases and therefore the growth rate increases. However, the diameter of the AlN particle at the end of solidification decreases due to the shorter growth time, and the particle is entrapped sooner by the solid/liquid interface.

As shown in Figure 8a, the highest nitrogen concentrations appear at a larger solid fraction with the increase in cooling rate. This is due to the fact that the growth time is shortened with increased cooling rate, and the solutes in molten steel enriched by micro-segregation cannot be consumed within the shorter period. Figure 9a confirms that for the same solid fraction, the size of the AlN particle is larger with the lower cooling rates since there is more time available for particle growth.

Figure 8 also shows that, for different cooling rates, the nitrogen contents at the end of solidification are almost identical, which indicates that the total mass of AlN formed at different cooling rates are almost the same. This is consistent with the experimental results shown in Figure 3c.

Figure 10 shows the effect of the nitrogen content on the phase transition temperature. This diagram was calculated with Factsage software based on the composition shown in Table 1. Although the liquidus and solidus temperatures change little with the increase in nitrogen content, the AlN precipitation temperature increases and therefore the difference between the start of precipitation and the solidus temperature also increases, which means the growth time of AlN is longer for the same cooling rate and the size of $\mathrm{AlN}$ particles in the $\mathrm{FeCrAl}$ alloy increases. 
Based on this analysis, it is confirmed that measures taken to increase the cooling rate and/or reduce the nitrogen content in the molten alloy will decrease the size of AlN particles precipitated in FeCrAl stainless steel.

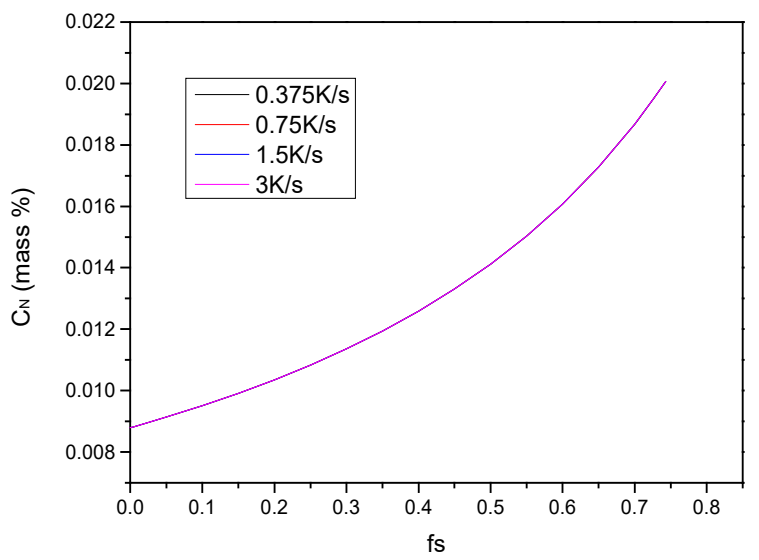

Figure 7. The average nitrogen content in molten steel from liquidus temperature to the beginning of AlN precipitation.

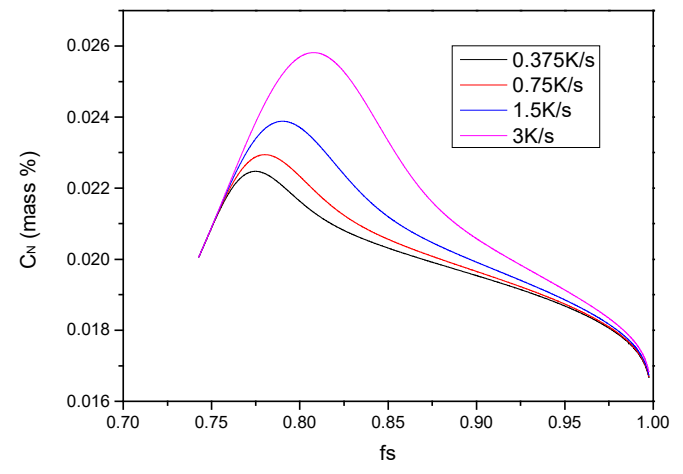

(a)

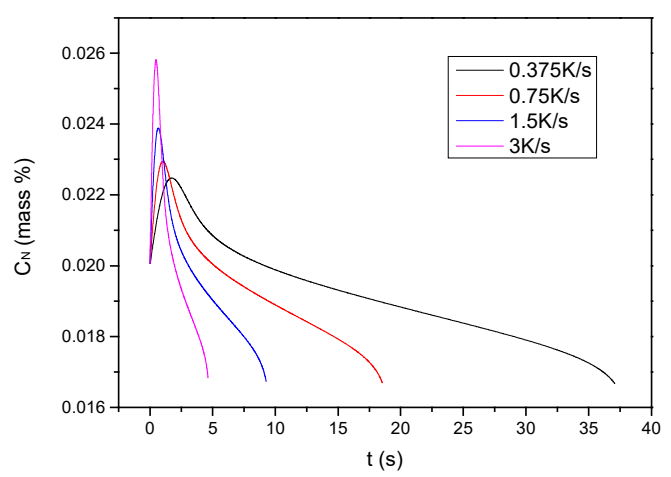

(b)

Figure 8. Predicted change in average nitrogen content of molten steel during solidification at different cooling rates after AlN begins to precipitate: (a) the variation with solid fraction, (b) the variation with growth time of AlN.

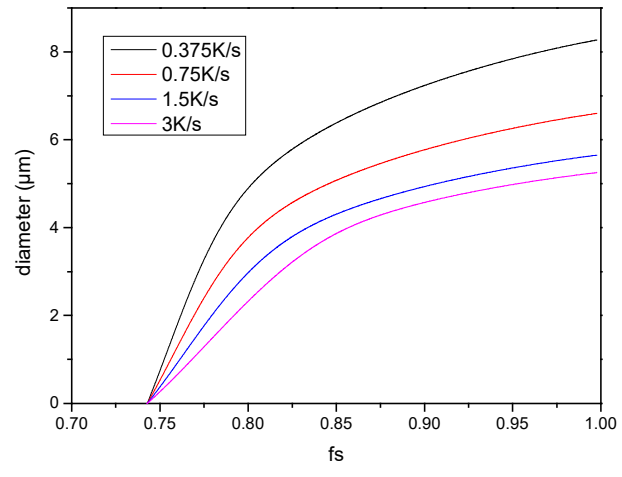

(a)

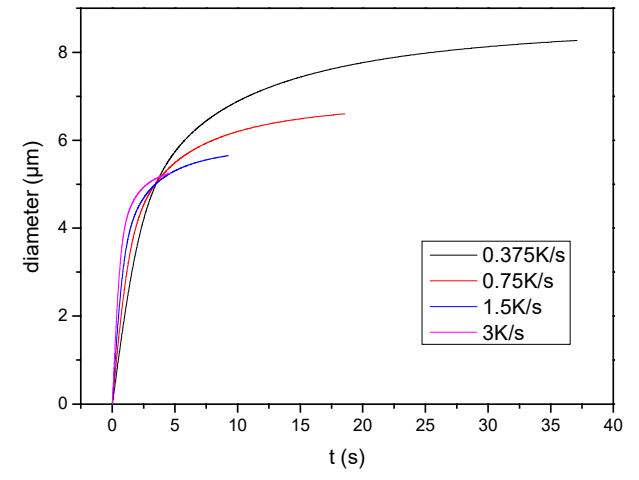

(b)

Figure 9. Calculated diameters of AlN particles during solidification at different cooling rates: (a) the variation with solid fraction, (b) the variation with growth time of AlN. 


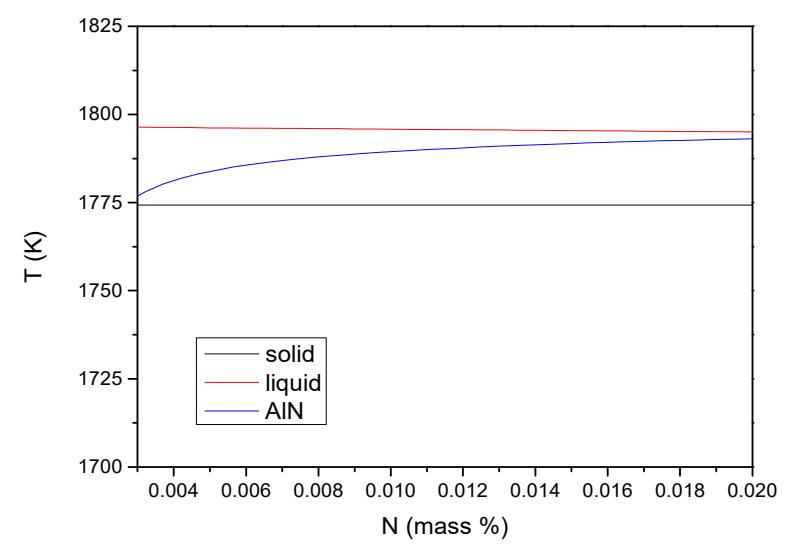

Figure 10. Effect of nitrogen content on phase transition temperatures.

\section{Conclusions}

The size and number of AlN particles in FeCrAl stainless steel were investigated with the aid of unidirectional experiments in order to determine the mechanism of AlN particle growth during solidification. The observations were then compared with values calculated using a diffusion-controlled growth model. The results can be summarized as follows:

1. During solidification, AlN precipitates within the mushy zone. The size of AlN particles decreases and the number of AlN particles increases with increasing cooling rate, although the volume fraction is relatively unaffected.

2. The particle sizes predicted with the aid of a diffusion-controlled growth model correlate well with the size of AlN particles observed in samples obtained from the unidirectional solidification experiments.

3. The model results also confirm that $\mathrm{AlN}$ particles in the $\mathrm{FeCrAl}$ alloy grow during solidification when the solute content in the liquid exceeds the concentration in equilibrium with AlN.

4. The calculated results show that after AlN begins to precipitate, the nitrogen content in the molten alloy varies significantly with the cooling rate.

5. Higher cooling rates result in shorter growth times and consequently AlN particles of smaller size.

6. Smaller AlN particles can also be achieved by reducing the nitrogen content in the molten alloy.

Author Contributions: Conceptualization, Z.D., Y.H., J.L. and B.Y.; Data curation, Z.D.; Formal analysis, Z.D.; Funding acquisition, J.L.; Investigation, Z.D.; Methodology, Z.D.; Project administration, J.L.; Resources, J.L.; Software, Z.D.; Supervision, J.L. and B.Y.; Validation, J.L., B.Y. and A.M.; Visualization, Z.D.; Writing一original draft, Z.D.; Writing-review and editing, Y.H., Y.Y. and A.M.

Funding: This research was funded by the National Natural Science Foundation of China, grant number 51874028.

Conflicts of Interest: The authors declare no conflict of interest.

\section{References}

1. Sastry, S.D.; Rohatgi, P.K.; Abraham, K.P.; Prasad, Y.V.R.K. Mechanism of strengthening in high temperature treated Fe12Cr6Al ferritic stainless steel. Scr. Metall. 1979, 13, 817-822. [CrossRef]

2. Inoue, Y.; Kikuchi, M.; Tendo, M.; Kajimura, H. Oxidation behavior of Al-containing ferritic stainless steel in an exhaust gas atmosphere. J. Jpn. Inst. Met. 2006, 70, 880-889. [CrossRef]

3. Liu, F.; Halvarsson, M.; Hellström, K.; Svensson, J.E.; Johansson, L.G. First Three-Dimensional Atomic Resolution Investigation of Thermally Grown Oxide on a FeCrAl Alloy. Oxid. Met. 2015, 83, 441-451. [CrossRef]

4. He, Y.; Wang, F.; Li, C.; Yang, Z.; Zhang, J.; Li, Y. Effect of Mg content on the hot ductility of wrought Fe-36Ni alloy with Ti addition. Mater. Sci. Eng. A 2016, 673, 99-107. [CrossRef] 
5. Dekkers, R.; Blanpain, B.; Wollants, P.; Haers, F.; Vercruyssen, C.; Gommers, B. Non-metallic inclusions in aluminium killed steels. Ironmak. Steelmak. 2002, 29, 437-444. [CrossRef]

6. Deng, Z.; Zhu, M. Evolution Mechanism of Non-metallic Inclusions in Al-Killed Alloyed Steel during Secondary Refining Process. ISIJ Int. 2013, 53, 450-458. [CrossRef]

7. Massardier, V.; Ngansop, A.; Fabrègue, D.; Merlin, J. Identification of the parameters controlling the grain refinement of ultra-rapidly annealed low carbon Al-killed steels. Mater. Sci. Eng. A 2010, 527, 5654-5663. [CrossRef]

8. Herrera, M.; Castro, F.; Castro, M.; Méndez, M.; Solís, H.; Castellá, A.; Barbaro, M. Modification of $\mathrm{Al}_{2} \mathrm{O}_{3}$ inclusions in medium carbon aluminium killed steels by AlCaFe additions. Ironmak. Steelmak. 2006, 33, 45-51. [CrossRef]

9. Goto, H.; Miyazawa, K.; Yamada, W.; Tanaka, K. Effect of the Cooling Rate on Compositions of the Oxides Precipitated during Solidification of Steels. ISIJ Int. 1995, 35, 708-714. [CrossRef]

10. He, Y.; Liu, J.; Qiu, S.; Deng, Z.; Yang, Y.; McLean, A. Thermodynamic analysis of inclusion characteristics in as-cast FeCrAl-(La) alloys. Ironmak. Steelmak. 2018, 1-9. [CrossRef]

11. Lorig, C.H.; Elsea, A.R. Occurrence of intergranular fracture in cast steels. Transactions 1947, 55, 160.

12. Turkdogan, E.T. Causes and effects of nitride and carbonitride precipitation during continuous casting. Iron Steelmak. 1989, 16, 61.

13. Leger, M.-T.; Guillaume, B. Microfractographic Diagnosis of the Embrittlement of Steel Castings by Aluminum. Int. Cast Met. J. 1980, 5, 40-46.

14. Funnell, D.G.; Davies, J.R. Effect of aluminium nitride particles on hot ductility of steel. Met. Technol. 1978, 5, 150-153. [CrossRef]

15. Tacikowski, M.; Osinkolu, G.A.; Kobylanski, A. The synergetic effect of aluminium nitride precipitation and sulphur segregation on hot intergranular brittleness of high purity iron alloys. Acta Metall. 1988, 36, 995-1004. [CrossRef]

16. Choudhary, S.K.; Ghosh, A. Mathematical Model for Prediction of Composition of Inclusions Formed during Solidification of Liquid Steel. ISIJ Int. 2009, 49, 1819-1827. [CrossRef]

17. You, D.; Michelic, S.K.; Presoly, P.; Liu, J.; Bernhard, C. Modeling Inclusion Formation during Solidification of Steel: A Review. Metals 2017, 7, 460. [CrossRef]

18. Han, Z.; Liu, J.; He, Y. Solidification Structure and Inclusions of Ti-containing FeCrAl Stainless Steel. Iron Steel Vanadium Titan. 2016, 37, 125-132.

19. Lindborg, U. A Collision Model for the Growth and Separation of Deoxidation Products. Trans. Metall. Soc. AIME 1968, 242, 94.

20. Sakao, H.; Ito, K.; Wanibe, Y. Principles of deoxidation. Tetsu-to-Hagané 1971, 57, 1863-1882. [CrossRef]

21. Suzuki, M.; Yamaguchi, R.; Murakami, K.; Nakada, M. Inclusion Particle Growth during Solidification of Stainless Steel. ISIJ Int. 2001, 41, 247-256. [CrossRef]

22. Inouye, M.; Kojima, Y.; Choh, T.; Uekawa, S.; Yamada, Y. On the measurements of diffusion coefficients of nitrogen in the liquid Fe. Tetsu-to-Hagane 1973, 59, 205-213. [CrossRef]

23. Ueshima, Y.; Isobe, K.; Mizoguchi, S.; Maede, H.; Kajioka, H. Analysis of the Rate of Crystallization and Precipitation of MnS in the Resulphurized Free-cutting Steel. Tetsu-to-Hagané 1988, 74, 465-472. [CrossRef]

24. Liu, Z.; Wei, J.; Cai, K. A Coupled Mathematical Model of Microsegregation and Inclusion Precipitation during Solidification of Silicon Steel. ISIJ Int. 2002, 42, 958-963. [CrossRef]

25. Saffman, P.G.; Turner, J.S. On the collision of drops in turbulent clouds. J. Fluid Mech. 1956, 1, 16-30. [CrossRef]

26. Goto, H.; Miyazawa, K.; Yamaguchi, K.; Ogibayashi, S.; Tanaka, K. Effect of Cooling Rate on Oxide Precipitation during Solidification of Low-Carbon Steels. ISIJ Int. 1994, 34, 414-419. [CrossRef]

27. Ma, Z.; Janke, D. Characteristics of Oxide Precipitation and Growth during Solidification of Deoxidized Steel. ISIJ Int. 1998, 38, 46-52. [CrossRef]

28. Aakuma, T. Growth of Carbide and Nitride Particle in Steel. Bull. Jpn. Inst. Met. 1981, 20, 247-256.

29. Chiu, S.N.; Stoyan, D.; Kendall, W.S.; Mecke, J. Stochastic Geometry and Its Applications; John Wiley \& Sons: Hoboken, NJ, USA, 2013; ISBN 1118658256.

30. Ohnaka, I. Mathematical analysis of solute redistribution during solidification with diffusion in solid phase. Trans. Iron Steel Inst. Jpn. 1986, 26, 1045-1051. [CrossRef] 
31. Won, Y.-M.; Thomas, B.G. Simple model of microsegregation during solidification of steels. Metall. Mater. Trans. A 2001, 32, 1755-1767. [CrossRef]

32. He, Y.; Liu, J.; Han, Z.; Deng, Z.; Su, X.; Ji, Y. Phase transformation and precipitation during solidification of FeCrAl alloy for automobile exhaust gas purifying systems. J. Alloy. Compd. 2017, 714, 251-257. [CrossRef]

33. Deng, Z.; Liu, J.; He, Y.; Han, Z.; Su, X.; Ding, H. Phase transformations and precipitation behavior in FeCrAl stainless steel during equilibrium solidification. Chin. J. Eng. 2017, 39, 710-720.

34. Hino, M.; Ito, K. Thermodynamic Data for Steelmaking; Tohoku University Press: Sendai, Japan, 2010.

35. Wagner, C. Thermodynamics of Alloys; Addison-wesley: Boston, MA, USA, 1952.

36. Jo, J.-O.; Jung, M.-S.; Park, J.-H.; Lee, C.-O.; Pak, J.-J. Thermodynamic Interaction between Chromium and Aluminum in Liquid Fe-Cr Alloys Containing 26 mass\% Cr. ISIJ Int. 2011, 51, 208-213. [CrossRef]

37. Wang, Y.N.; Yang, J.; Xin, X.L.; Wang, R.Z.; Xu, L.Y. The Effect of Cooling Conditions on the Evolution of Non-metallic Inclusions in High Manganese TWIP Steels. Metall. Mater. Trans. B Process. Metall. Mater. Process. Sci. 2016, 47, 1378-1389. [CrossRef]

38. Villegas, E.A. The diffusion of nitrogen in liquid iron alloys at 16000C. Ph.D. Thesis, Stanford University, Stanford, CA, USA, 1976. Dep. Appl. Geosci., 247.

39. Goto, H.; Miyazawa, K.; Honma, H. Effect of the Primary Oxide on the Behavior of the Oxide Precipitated during Solidification of Steel. ISIJ Int. 1996, 36, 537-542. [CrossRef]

(C) 2019 by the authors. Licensee MDPI, Basel, Switzerland. This article is an open access article distributed under the terms and conditions of the Creative Commons Attribution (CC BY) license (http://creativecommons.org/licenses/by/4.0/). 